\title{
Effective therapy of experimental human malignant melanomas with a targeted cytotoxic somatostatin analogue without induction of multi-drug resistance proteins
}

\author{
GUNHILD KELLER ${ }^{1,2}$, ANDREW V. SCHALLY ${ }^{1,2}$, ATTILA NAGY $^{1,2}$, \\ BENJAMIN BAKER $^{1,2}$, GABOR HALMOS ${ }^{1,2}$ and JÖRG B. ENGEL ${ }^{1,2}$ \\ ${ }^{1}$ Endocrine, Polypeptide and Cancer Institute, Veterans Affairs Medical Center; ${ }^{2}$ Section of Experimental Medicine, \\ Department of Medicine, Tulane University School of Medicine, New Orleans, LA 70112, USA
}

Received August 22, 2005; Accepted February 2, 2006

\begin{abstract}
Malignant melanomas are characterized by a high intrinsic resistance to chemotherapy. Multiple drug resistance (MDR) can be mediated by transport proteins such as MDR-1, multidrug resistance-associated protein (MRP) or lung resistance protein (LRP). The cytotoxic analogue of somatostatin AN-238 consisting of 2-pyrrolinodoxorubicin (AN-201) linked to a somatostatin analogue RC-121 binds to receptors for somatostatin and is targeted to tumors expressing these receptors. We evaluated the expression of somatostatin receptors on human malignant melanoma tumor lines MRIH255 and MRI-H187 and examined the effects of the targeted analogue AN-238 and its cytotoxic radical AN-201 on growth of these tumors in nude mice. We also studied the effects of AN-238 and AN-201 on the expression of MDR-1, MRP-1 and LRP by real-time PCR. AN-238 inhibited the growth of MRIH255 and MRI-H187 tumors while AN-201 was ineffective. Blockade of somatostatin receptors by somatostatin analogue RC-121 abolished the effects of AN-238. Targeted therapy with AN-238 did not produce an induction of mRNA of MDR-1, MRP-1 or LRP. Our findings show that targeted chemotherapy with cytotoxic somatostatin analogue AN-238 inhibits the growth of malignant melanomas. AN-238 could provide a novel treatment approach for advanced malignant melanomas.
\end{abstract}

\section{Introduction}

In the past four decades, the incidence of malignant melanoma has increased steadily. Currently, melanoma ranks as the fifth

Correspondence to: Dr Andrew V. Schally, Department of Veterans Affairs, Medical Center, 1201 N.W. 16th Street, Miami, FL 33125-1693, USA

Abbreviations: MDR, multiple drug resistance; MRP, multidrug resistance-associated protein; LRP, lung resistance protein

Key words: malignant melanomas, somatostatin, multi-drug resistance most common cancer among men in the US and sixth in women with an estimated 60,000 new cases in both sexes in 2005 (1). When diagnosed early, melanoma can be cured by wide surgical excision. However, metastatic disease remains generally incurable with a median survival time of 7.5 months and a five-year survival rate of $5.5 \%$ (2). Various therapeutic modalities are available for the treatment of metastatic melanoma including surgical resection of metastatic lesions $(3,4)$, chemotherapy with dacarbazine (DTIC) $(5,6)$ and immunotherapy with tumor cell vaccines $(4,7,8)$ as well as biological response modifiers $(9,10)$. Although promising clinical results were reported, no improvement in overall survival was achieved during the past 22 years (2). Thus, novel more effective treatment strategies are needed.

The elucidation of molecular characteristics of malignant cells prompted the development of a new class of drugs known as targeted therapeutics. These include inactivators of genes or gene products involved in oncogenesis, antibodies against tumor surface structures and conjugates consisting of tumorspecific ligands linked to toxins, radionuclides or chemotherapeutic agents (11-14). Targeted chemotherapy can be based on peptide hormone ligands, which directly deliver the cytotoxic agents to tumor cells expressing the corresponding receptors $(15,16)$. Since binding sites for somatostatin have been detected on various malignant cells (17), we developed a cytotoxic somatostatin analogue, $\mathrm{AN}-238$, consisting of the somatostatin carrier octapeptide RC-121 (D-Phe-Cys-Tyr-DTrp-Lys-Val-Cys-Thr- $\mathrm{NH}_{2}$ ) linked covalently to a highly potent derivative of doxorubicin (DOX), 2-pyrrolino-DOX (AN-201). AN-238 binds with high affinity to somatostatin receptor subtypes 2 and $5\left(\mathrm{sst}_{2}\right.$ and $\left.\mathrm{sst}_{5}\right)$ and with medium affinity to $\mathrm{sst}_{3}(15)$. In experimental models of tumors expressing somatostatin receptors, targeted therapy with AN-238 induces a substantially greater tumor inhibition than the non-targeted radical AN-201 (18-23).

Receptors for somatostatin were found in a high percentage of malignant melanomas with $96 \%$ of the tumors expressing $\mathrm{sst}_{1}, 83 \% \mathrm{sst}_{2}, 61 \% \mathrm{sst}_{3}, 57 \%, \mathrm{sst}_{4}$ and $9 \% \mathrm{sst}_{5}$ (24). In clinical studies, radiolabeled SST analogues were successfully used to detect metastatic lesions of malignant melanomas $(25,26)$. Consequently, receptors for SST on malignant melanomas 
could be used for targeted therapy with the cytotoxic somatostatin analogue AN-238.

Metastatic malignant melanomas are highly resistant to a wide variety of chemotherapeutic agents. Multiple drug resistance (MDR) of tumor cells can be mediated by several proteins with different mechanisms of action. P-glycoprotein (Pgp), the product of the MDR-1 gene and the recently discovered MDR related protein 1 (MRP-1) increase the cellular efflux of chemotherapeutic drugs (27), while vault proteins, such as lung resistance protein (LRP), are involved in the drug transport from the nucleus to the cytoplasma $(28,29)$. LRP protein has been detected in human specimens of malignant melanomas with the highest expression in metastatic tissue exposed to chemotherapy (30). Targeted chemotherapy leads to an increased concentration of the chemotherapeutic agent in the malignant tissue and treatment with cytotoxic analogues such as AN-238 could overcome MDR caused by drug transport proteins.

In the current study, we evaluated the antitumor activity of the cytotoxic somatostatin analogue AN-238 in two models of human malignant melanomas xenografted into nude mice. In addition, we examined the effects of AN-238 and its nontargeted cytotoxic radical (AN-201) on the expression levels of MDR-1, MRP-1 and LRP.

\section{Materials and methods}

Peptides and cytotoxic agents. The somatostatin octapeptide carrier RC-121 (D-Phe-Cys-Tyr-D-Trp-Lys-Val-Cys-Thr$\mathrm{NH}_{2}$ ) and cytotoxic radical AN-201 were synthesized in our laboratory as described $(31,32)$. AN-238 was made by coupling AN-201-14-O-hemiglutarate to the $\mathrm{NH}_{2}$ terminus of [Lys-(N(9-fluorenyl) methoxycarbonyl ${ }^{5}$ ] RC-121, followed by deprotection and purification (33). Before the i.v. injection, the compounds were dissolved in $20 \mu 1$ of $0.01 \mathrm{~N}$ aqueous acetic acid and diluted with $5 \%(\mathrm{w} / \mathrm{v})$ aqueous D-mannitol solution (Sigma, St. Louis, MO) to the final volume.

Tumor lines. The two transplantable human melanoma tumor lines MRI-H255 and MRI-H187 were obtained as frozen tumor tissues from the National Cancer Institute (Frederick Cancer Research and Development Center, MD). Thawing and transplantation procedures were carried out as recommended.

Animals. Five- to six-week-old female athymic nude mice (Ncr nu/nu) were obtained from the National Cancer Institute (NCI, Bethesda, MD, USA). The animals were housed in sterile cages under laminar flow hoods in a temperaturecontrolled room with a 12-h light/12-h dark schedule and were fed autoclaved chow and water ad libitum.

Experimental protocol. Tumors resulting 8 weeks after transplantation in donor animals were aseptically dissected and mechanically minced. Pieces of tumor tissue $\left(\sim 3 \mathrm{~mm}^{3}\right)$ were transplanted subcutaneously (s.c.) into the experimental animals by a trocar needle. Tumor volume (length $\mathrm{x}$ width $\mathrm{x}$ height $\mathrm{x}$ 0.5236) and body weight were measured weekly. At the end of each experiment, mice were sacrificed under anaesthesia, tumors were excised and weighed and necropsy was performed. Tumor specimens were snap frozen and stored at $-70^{\circ} \mathrm{C}$. All experiments were in accordance with the institutional guidelines for the welfare of animals in experiments.

Experiment 1. Mice-bearing MRI-H255 melanomas with a mean tumor volume of $100 \mathrm{~mm}^{3}$ were assigned to three groups of 9 animals each. The animals received the following treatment as a single injection into the jugular vein: Group 1, control, vehicle solution (5\% mannitol); group 2, cytotoxic analogue AN-238 at a dose of $250 \mathrm{nmol} / \mathrm{kg}$; group 3, cytotoxic radical AN-201 at a dose of $250 \mathrm{nmol} / \mathrm{kg}$. The experiment was terminated on day 22 .

Experiment 2. Animals with MRI-H255 tumors with a mean tumor size of about $50 \mathrm{~mm}^{3}$ were divided into six groups and received the following treatment on day 1 and day 15: Group 1, control, vehicle solution (10 mice); group 2, AN-238 at $200 \mathrm{nmol} / \mathrm{kg}$ (10 mice); group 3, AN-201 at $200 \mathrm{nmol} / \mathrm{kg}$ (10 mice); group 4, the carrier RC-121 at a dose of $200 \mathrm{nmol} /$ $\mathrm{kg}$ (5 mice); group 5, unconjugated mixture of the cytotoxic radical AN-201 and the carrier RC-121 at a dose of $200 \mathrm{nmol} /$ $\mathrm{kg}$ (5 mice); group 6, $200 \mu \mathrm{g}$ of RC-121 i.v. $15 \mathrm{~min}$ prior to the i.v. injection of cytotoxic analogue $\mathrm{AN}-238$ at $200 \mathrm{nmol} / \mathrm{kg}$ (5 mice). The experiment was terminated after 28 days.

Experiment 3. Animals bearing MRI-H187 melanomas were assigned to three groups of 10 mice each when tumors had reached a size of $60-70 \mathrm{~mm}^{3}$ and received the following treatment as i.v. injections on day 1: Group 1, control, vehicle solution; group 2, AN-238 at $200 \mathrm{nmol} / \mathrm{kg}$; group 3, AN-201 at $200 \mathrm{nmol} / \mathrm{kg}$. The experiment was terminated on day 22 .

Evaluation of toxicity. General toxicity was evaluated on the bases of total leukocyte count (WBC), loss of body weight and macroscopic changes of somatostatin receptor-bearing organs. WBC was determined with the Unopette microcollection kit (Becton Dickinson, Franklin Lakes, NJ) before and seven days after the drug administration. Body weights were measured weekly. Somatostatin receptor-bearing organs such as brain, gastrointestinal tract and kidneys were weighed and examined during necropsy.

$R N A$ isolation and reverse transcription (RT) PCR. Total RNA was extracted from tumors by using the TRI-Reagent ${ }^{\circledR}$ kit (Sigma-Aldrich Co., St. Louis, MO, USA), following the manufacturer's instructions. RNA was subjected to RT using the RNA PCR core kit (Applied Biosystems, Norwalk, CT, USA) according to the manufacturer's instructions. RNA ( $1 \mu \mathrm{g})$ was transcribed into cDNA in a final volume of $20 \mu 1$. All PCR reactions were performed in an Applied Biosystems PCR system 2700 (Applied Biosystems, Norwalk, CT, USA). For amplification of cDNA transcripts, gene-specific primers for somatostatin receptors $1-5\left(\mathrm{sst}_{1-5}\right)$ were used as described in detail $(34,35)$. A total RNA negative control which contained water in the RT reaction was used to rule out genomic DNA contamination. PC-3 human androgen independent human prostate cancer served as a positive control.

Western immunoblot analysis. For immunodetection of $\mathrm{sst}_{2}$ and $\mathrm{sst}_{5}$, an extraction of membrane proteins from untreated MRI-H255 and MRI-H187 was performed as reported (36-38). 


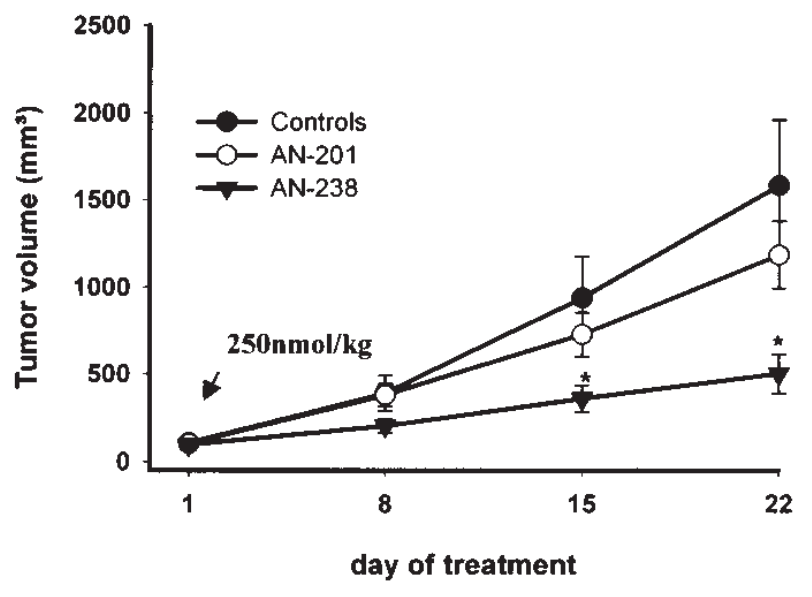

Figure 1. Effects of targeted cytotoxic somatostatin analogue AN-238 and its radical AN-201 on the growth of MRI-H255 human malignant melanoma xenografted into nude mice. Arrow indicates treatment, ${ }^{*} \mathrm{p}<0.05$ vs. controls.

The presence of $\mathrm{sst}_{2}$ and $\mathrm{sst}_{5}$ receptor protein was then demonstrated by Western blotting using two goat polyclonal human $\mathrm{sst}_{2}$ and $\mathrm{sst}_{5}$ antibodies at a dilution of 1:250 (Santa Cruz Biotechnology, Santa Cruz, CA), as described (38).

Receptor-binding assay. Binding characteristics of somatostatin receptors on tumor membrane preparation of control animals in both melanoma tumor lines were evaluated by ligand competition assay using ${ }^{125}$ I-labeled somatostatin octapeptide RC-160, as described previously $(34,35)$. The Ligand PC computerized curve-fitting program was used to determine the type of receptor binding, the dissociation constant $\left(\mathrm{K}_{\mathrm{d}}\right)$, and the maximal binding capacity $\left(\mathrm{B}_{\max }\right)$ of receptors $(34,35)$.

Real-time PCR for MDR-1, LRP and MRP mRNA expression. Total RNA was isolated from $\sim 100 \mathrm{mg}$ of tumor tissue for each sample according to the TRI-Reagent protocol. Total RNA $(1 \mu \mathrm{g})$ was subjected to reverse transcription with the Iscript cDNA synthesis kit (BioRad) following the manufacturer's protocol. Real-time PCR was employed to measure drug resistance gene expression using the SYBR Green system (BioRad). Primers for MDR-1 (sense 5'-TCT GGA GGA AGA CAT GAC CAG GTA-3'; antisense 5'-GGC ACC AAA ATG AAA CCT GAA TGT-3'), MRP-1 (sense 5'-AGA GAC AGC TCA GCA GCT CCT-3'; antisense 5'GCC TTG TCA GCC TCC ATC AG-3'), LRP (5'-ATCATT CAGGCCACCATCATCAG-3'; antisense 5'-AACACCG CTGGGAGGTACG-3') and $B$-actin (sense 5'-CTG GAA CGG TGA AGG TGA CA-3'; antisense 5'-AAG GGA CTT CCT GTA ACA ATG CA-3') were used to measure gene expression. The thermal cycling conditions comprised an initial denaturation step at $95^{\circ} \mathrm{C}$ for $3 \mathrm{~min}$, then 40 cycles of two-step PCR including $95^{\circ} \mathrm{C}$ for $15 \mathrm{sec}$ and $60^{\circ} \mathrm{C}$ for $1 \mathrm{~min}$. Data were collected during the $60^{\circ} \mathrm{C}$ annealing step and were further analyzed by the i-Cycler iQ optical system software (Bio-Rad). Real-time PCR efficiencies (E) for MDR-1 (target gene 1), MRP (target gene 2) and $B$-actin (reference gene) were calculated from the given slopes in the iCycler software according to the following equation: $\mathrm{E}=10^{[-1 / \mathrm{slope}]}$ (39). Three

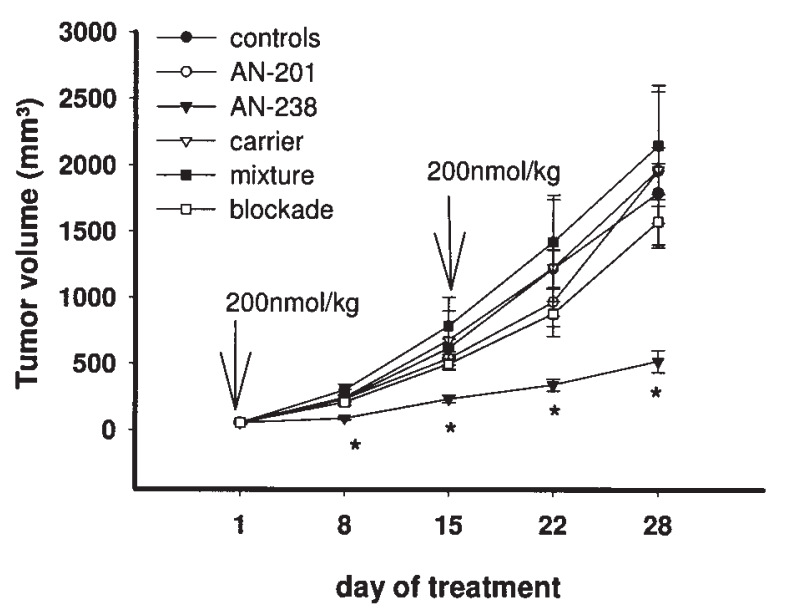

Figure 2. Effects of targeted cytotoxic somatostatin analogue AN-238, the radical $\mathrm{AN}-201$, the carrier somatostatin analogue $\mathrm{RC}-121$, a mixture of AN-201 and RC-121, and AN-238 after receptor blockade with a high dose of somatostatin analogue RC-121 on the growth of MRI-H255 human malignant melanoma xenografted into nude mice. Arrow indicates treatment, ${ }^{*} \mathrm{p}<0.05$ vs. controls

tumor samples from experiment 2 and 3 (control, the AN-238 and the AN-201 group) were analyzed in triplicates. For the mathematical model used in this study it was necessary to determine the crossing points for the transcripts of each sample. Crossing points (CPs) are defined as the number of cycles at which the fluerescense rises appreciably above the background fluorescence. Using $\mathrm{CP}$ deviations $(\triangle \mathrm{CP})$ for control and treatment $\left(\mathrm{CP}_{\text {controls }}-\mathrm{CP}_{\text {treatment }}\right)$ of target and reference gene transcripts, quantification of the target genes in treated groups relative to the controls was performed using a mathematical model by Pfaffl (40):

Ratio $=\left(\mathrm{E}_{\text {target }}\right)^{\Delta C P \text { target (control-treatment) }}:\left(\mathrm{E}_{\text {reference }}\right)^{(\Delta C P \text { reference (control-treatment) }}$

Statistical analysis. Data are expressed as means \pm SE. Differences between mean values were evaluated by 2 -tailed Student's t-test. $\mathrm{p}<0.05$ was considered significant.

\section{Results}

Effects of treatment with cytotoxic AN-238 on tumor growth in vivo. In experiment 1, a single administration of AN-238 at $250 \mathrm{nmol} / \mathrm{kg}$ significantly $(\mathrm{p}<0.05)$ inhibited the growth of human MRI-H255 melanoma resulting in a $68.4 \%$ reduction of tumor volume compared to the controls. Tumor weight was also significantly $(\mathrm{p}<0.05)$ reduced by $64.6 \%$ and tumor doubling time was significantly prolonged as compared to control animals. Equimolar doses of the cytotoxic radical AN-201 had no significant effects on any tumor growth characteristics (Fig. 1 and Table I).

In experiment 2, administration of AN-238 at $200 \mathrm{nmol} / \mathrm{kg}$ on day 1 and day 15 significantly reduced the tumor volume of MRI-H255 melanomas from day 8 until the end of the experiment on day 29, the final tumor volume being $71.1 \%$ smaller than in the controls $(\mathrm{p}<0.001)$. Mean tumor weight was also significantly $(\mathrm{p}<0.001)$ decreased by $68.3 \%$. Equimolar doses of the cytotoxic radical AN-201, a mixture of AN-201 
Table I. Effects of therapy with cytotoxic somatostatin analogue AN-238, the cytotoxic radical AN-201, the carrier RC-121, an unconjugated mixture of AN-201 and RC-121, and AN-238 after blockade of the receptors with RC-121 on the growth of human melanomas MRI-H255 and MRI-H187 xenografted in nude mice.

\begin{tabular}{lllcl}
\hline Treatment & \multicolumn{1}{c}{ Initial } & $\begin{array}{c}\text { Tumor volume }\left[\mathrm{mm}^{3}\right] \\
\text { final }(\% \text { inhibition })\end{array}$ & $\begin{array}{c}\text { Tumor doubling time } \\
\text { [days] }\end{array}$ & $\begin{array}{c}\text { Tumor weight [mg] } \\
(\% \text { inhibition })\end{array}$ \\
\hline $\begin{array}{l}\text { Experiment 1: MRI-H255 } \\
\quad\end{array}$ & & & \\
$\quad$ Control & $107.4 \pm 29.7$ & $1578.0 \pm 377.2$ & $5.4 \pm 0.3$ & $2212.5 \pm 638.7$ \\
AN-238 & $97.0 \pm 20.8$ & $498.9 \pm 113.3^{\mathrm{a}}(68.4)$ & $8.9 \pm 0.8^{\mathrm{b}}$ & $783.8 \pm 247.9(64.6)^{\mathrm{a}}$ \\
AN-201 & $103.6 \pm 21.6$ & $1180.5 \pm 190.8(25.2)$ & $6.2 \pm 0.4$ & $1695.0 \pm 489.3(23.4)$ \\
Experiment 2: MRI-H255 & & & & \\
Control & $53.4 \pm 7.6$ & $1790.0 \pm 226.1$ & $5.7 \pm 0.2$ & $2074.0 \pm 244.3$ \\
AN-238 & $52.3 \pm 4.4$ & $517.4 \pm 83.3^{\mathrm{c}}(71.1)$ & $9.3 \pm 0.7^{\mathrm{c}}$ & $658.2 \pm 106.7^{\mathrm{c}}(68.3)$ \\
AN-201 & $52.2 \pm 5.2$ & $1958.6 \pm 177.7(-9.4)$ & $5.4 \pm 0.2$ & $2231.9 \pm 221.5(-7.6)$ \\
Carrier & $50.9 \pm 10.9$ & $1966.1 \pm 588.1(-9.8)$ & $5.5 \pm 0.4$ & $2298.2 \pm 684.8(-10.8)$ \\
Mixture & $51.1 \pm 8.1$ & $2148.1 \pm 454.5(-20.0)$ & $5.4 \pm 0.3$ & $2760.8 \pm 573.2(-33.1)$ \\
Blockade & $51.0 \pm 6.2$ & $1572.4 \pm 171.6(12.2)$ & $5.7 \pm 0.1$ & $1594.1 \pm 151.7(23.1)$ \\
Experiment 3: MRI-H187 & & & & \\
Control & $70.3 \pm 7.9$ & $1058.8 \pm 113.8$ & $5.7 \pm 0.2$ & $1448.6 \pm 144.4$ \\
AN-238 & $62.4 \pm 8.2$ & $364.4 \pm 37.8^{\mathrm{c}}(66.6)$ & $8.9 \pm 0.8^{\mathrm{c}}$ & $521.3 \pm 58.8^{\mathrm{c}}(64.0)$ \\
N-201 & $63.4 \pm 8.4$ & $805.0 \pm 114.0(24.0)$ & $6.1 \pm 0.2$ & $1144.4 \pm 146.6(21.0)$ \\
\hline
\end{tabular}

${ }^{\mathrm{a}} \mathrm{p}<0.05$ vs. controls; ${ }^{\mathrm{b}} \mathrm{p}<0.01$ vs. controls; ${ }^{\mathrm{c}} \mathrm{p}<0.001$ vs. controls.

and somatostatin analogue RC-121 or carrier RC-121 alone had no significant effects on any tumor growth characteristics. The effect of AN-238 could be blocked by injecting $200 \mu \mathrm{g}$ of the somatostatin analogue RC-121, 15 min prior to the administration of AN-238 (Fig. 2 and Table I).

In experiment 3, a single dose of AN-238 at $200 \mathrm{nmol} / \mathrm{kg}$ significantly reduced tumor volume of MRI-H187 melanomas from day 8 until the end of the experiment on day 22 (Fig. 2) when the final tumor volume was $66.6 \%(\mathrm{p}<0.001)$ smaller than in the control group. Tumor weights in the group treated with AN-238 were $64.0 \%(\mathrm{p}<0.001)$ lower than in controls and tumor doubling time was significantly $(\mathrm{p}<0.001)$ extended. AN-201 had no significant effects on tumor growth (Fig. 2 and Table I).

Side effects and toxicity. In all treatment groups, except for the carrier group, a slight, reversible loss of body weight was observed 8 days after therapy, which ranged from $0.5-5.7 \%$ in the AN-238 groups and from 4.1-11.4\% in the AN-201 groups. In experiment 1, body weights in the AN-201 group were significantly decreased on day $8(\mathrm{p}<0.01)$ and on day 15 $(\mathrm{p}<0.01)$, as compared to controls. In experiment 2 , body weights were significantly $(\mathrm{p}<0.05)$ reduced on days 8,15 and 22 in the AN-201 group and in groups that received the mixture- and the blockade. No significant loss of body weight was observed after treatment with AN-238 (Fig. 3).

WBC was measured before and seven days after the injections. AN-238 did not significantly decrease the WBC in any of the three studies. However, AN-201 significantly $(\mathrm{p}<0.05)$ suppressed $\mathrm{WBC}$ on day 8 in all experiments. In

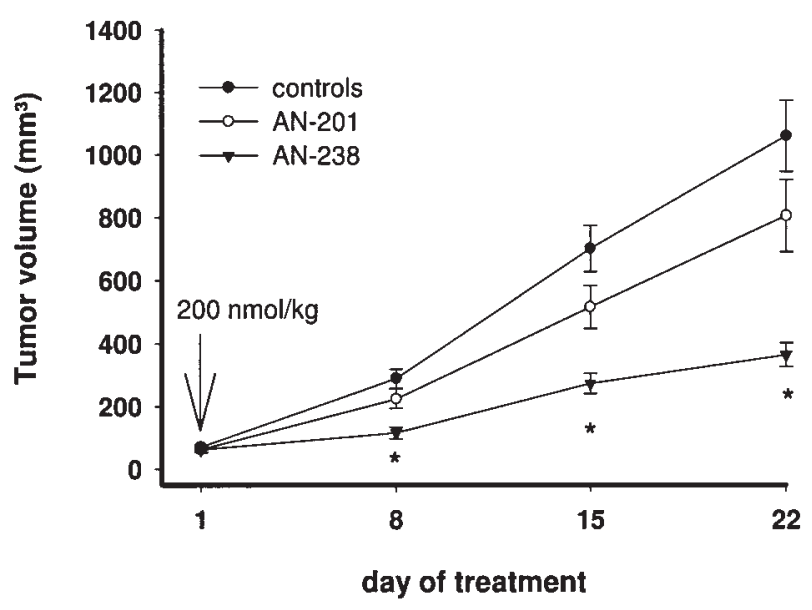

Figure 3. Effects of targeted cytotoxic somatostatin analogue AN-238 and its radical AN-201 on the growth of MRI-H187 human malignant melanoma xenografted into nude mice. Arrow indicates treatment, ${ }^{*} \mathrm{p}<0.05$ vs. controls.

experiment 2, the measurement prior to the second injection showed that the WBC was still significantly $(\mathrm{p}<0.05)$ below the normal range. A further decrease was found seven days after the second administration of AN-201.

Macroscopical or significant changes in organ weights were detected in somatostatin receptor-bearing organs were not observed in any of the experiments. One mouse died in the control group on day 5 in experiment 1 . In experiment 2 , one animal died on day 8 in the AN-201 group and one on day 26 
A

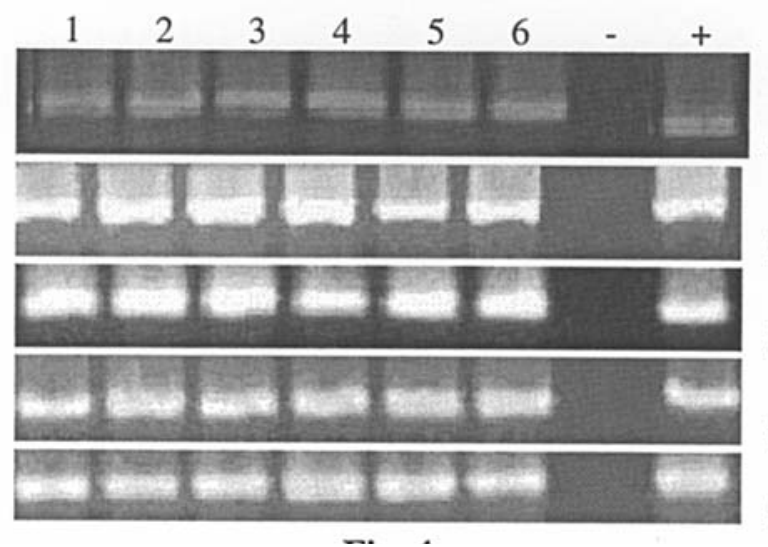

$\mathrm{SST}_{1}$

$\operatorname{SST}_{2 \mathrm{a}}$

$\mathrm{SST}_{3}$

$\mathrm{SST}_{4}$

$\mathrm{SST}_{5}$

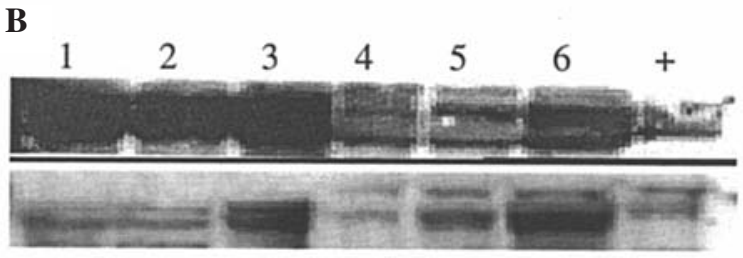

$\operatorname{SST}_{2 \mathrm{a}}$

$\mathrm{SST}_{5}$

Figure 4. (A) Expression of mRNA for somatostatin receptor subtypes 1-5 in human malignant melanomas MRI-H255 and MRI-H187 as revealed by RT-PCR. PCR products were separated on a $1.8 \%$ agarose gel and stained with ethidium bromide. mRNA expression for all five receptor subtypes was found with the expected size of $217 \mathrm{bp}$ for $\mathrm{sst}_{1}, 1104$ for $\mathrm{sst}_{2 \mathrm{a}}, 183$ for $\mathrm{sst}_{3}$, 278 for sst $_{4}$ and 222 for sst $_{5}$, in both human malignant melanoma tumor lines. Lanes 1-3, MRI-H255; lanes 4-6, MRI-H187; -, negative control; +, positive control (PC-3 human prostate carcinoma). (B) Expression of sst $_{2 \mathrm{a}}$ and $\mathrm{sst}_{5}$ protein as revealed by Western blot analysis. The receptor proteins were at the expected sizes of $43 \mathrm{kd}\left(\mathrm{sst}_{2 \mathrm{a}}\right)$ and $43 \mathrm{kd}\left(\mathrm{sst}_{5}\right) \mathrm{kd}$. Lanes 1-3 are MRIH255 tumors; lanes 4-6, MRI-H187 tumors; +, positive control (PC3 human prostate cancer).

in the AN-207 group. In experiment 3, one mouse died in the AN-201 group on day 17.

Expression and characteristics of somatostatin receptors. Using gene-specific primers, mRNA expression for all five receptor subtypes was found in both human melanoma tumor lines with the expected size of $217 \mathrm{bp}$ for $\mathrm{sst}_{1}, 1104 \mathrm{bp}$ for $\mathrm{sst}_{2 \mathrm{a}}$, 183 bp for $\mathrm{sst}_{3}, 278 \mathrm{bp}$ for $\mathrm{sst}_{4}$ and 222 bp for $\mathrm{sst}_{5}$ (Fig. 4A). The presence of $\mathrm{sst}_{2}$ and $\mathrm{sst}_{5}$ receptor protein in untreated MRI-H255 and MRI-H187 tumors was evaluated by Western blotting using specific antibodies. Specific bands showing two $43 \mathrm{kd}$ proteins for $\mathrm{sst}_{2}$ and $\mathrm{sst}_{5}$ protein were found in all investigated tumor samples (Fig. 4B).

Ligand competition assays showed a single class of high affinity-binding sites for somatostatin in membranes of MRIH255 and MRI-H187 human melanomas with a mean dissociation constant $\left(\mathrm{K}_{\mathrm{d}}\right)$ of $3.69 \pm 0.2 \mathrm{nM}$ in MRI-H255 tumors and $8.68 \pm 0.4 \mathrm{nM}$ in MRI-H187 tumors. The mean maximal-binding capacities $\left(\mathrm{B}_{\max }\right)$ were $321.8 \pm 4.9 \mathrm{fmol} / \mathrm{mg}$ membrane protein in MRI-H255 tumors and 505.9 $\pm 5.9 \mathrm{fmol} /$ mg membrane protein in MRI-H187 tumors, respectively.

MDR-1 and MRP-1 and LRP MRNA expression by real-time PCR. mRNA for MDR-1, MRP-1 and LRP was detected in

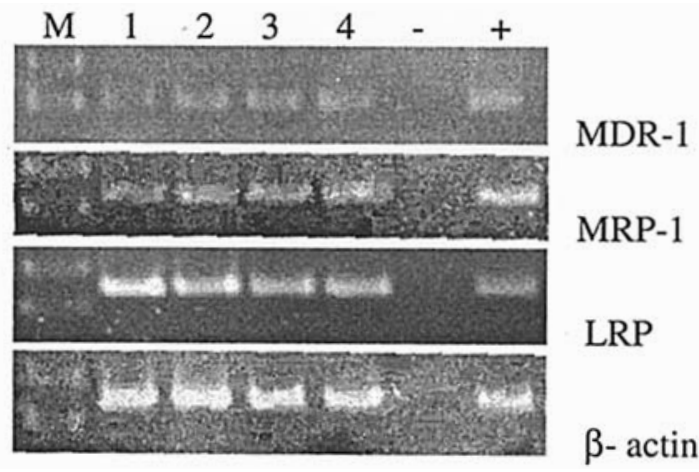

Figure 5. Expression of mRNA for MDR-1, MRP-1 and LRP in malignant melanomas as revealed by RT-PCR. PCR products were separated on a $1.8 \%$ agarose gel and stained with ethidium bromide. Specific bands with the expected of $95 \mathrm{bp}$ for MDR-1, $127 \mathrm{bp}$ for MRP-1 and $143 \mathrm{bp}$ for BCRP were found in both human malignant melanoma tumor lines. Lanes 1-2, MRI-H255 tumors; lanes 3-4, MRI-H187 tumors; -, negative control; +, positive control (A498 human renal cell cancer for MDR-1; H460 non-small cell human lung carcinoma for MRP-1 and LRP).

both cell lines (Fig. 5). The PCR products were of the expected sizes of $95 \mathrm{bp}$ for MDR-1, $127 \mathrm{bp}$ for MRP-1, $143 \mathrm{bp}$ for LRP and 140 bp for B-actin (Fig. 5). The efficiencies (E) were 1.989 for MDR-1, 1.999 for MRP-1, 2.050 for LRP and 1.997 for ß-actin. In MRI-H187 tumors, treatment with AN-201 caused a 3.78- and 1.69-fold induction of mRNA of MDR-1 and LRP, respectively; while no upregulation of MDR-1 or LRP was found after injection of AN-238. MRP-1 was not altered in either treatment group. In MRI-H255 tumors, therapy with AN-238 or AN-201 was not associated with major changes in mRNA expression for MDR-1, LRP and MRP-1 (data not shown).

\section{Discussion}

Malignant melanomas are characterized by their high intrinsic resistance to conventional chemotherapy. After standard therapy with dacarbazine, the response rates of patients with metastatic melanoma are as low as $11-28 \%$ and a complete tumor regression occurs in only $4 \%$ of the cases $(5,41)$. Other treatment approaches, such as combination chemotherapy based on various drugs and the recently introduced cytotoxic agent, temozolomide were not superior to the standard therapy $(8,42,43)$. Chemoresistance of neoplastic cells can be caused by different MDR proteins such as the transport proteins MDR-1 and MRP-1 that mediate drug efflux from tumor cells and LRP, which is involved in the transport of chemotherapeutic agents from the nucleus to the cytoplasma. Targeted chemotherapy was developed to increase the intratumoral concentration of cytotoxic radicals by a more selective drug delivery to malignant cells. This novel therapeutic approach results in a higher antitumor efficacy and may overcome MDR based on efflux proteins.

Somatostatin receptors are expressed in a high percentage of human malignant melanomas specimens (24). Accordingly, mRNA for all five subtypes of somatostatin receptors and specific-binding sites for a radiolabeled somatostatin analogue were detected in human MRI-H255 and MRI-H187 melanomas. The targeted cytotoxic somatostatin analogue AN-238 
significantly inhibited the growth of both MRI-H255 and MRI-H187 melanomas xenografted into nude mice, resulting in a $66.6-71.1 \%$ reduction in tumor volume and significantly prolonged the tumor doubling time in all experiments. Equimolar doses of the cytotoxic radical AN-201 did not affect any growth parameter. The carrier peptide, somatostatin analogue RC-121 or a mixture of AN-201 and RC-121 did not suppress the growth of MRI-H255 tumors, indicating that the effect of AN-238 is not due to the hormonal activity of the carrier octapeptide RC-121, but rather to its ability to deliver conjugated AN-201 to cancerous cells. The inhibitory effects of AN-238 on tumor growth could be abolished by blocking the tumoral somatostatin receptors with an excess of the somatostatin analogue RC-121. This result further supports the targeting concept.

In the current study, the toxicity of cytotoxic somatostatin analogue AN-238 and its radical AN-201 was evaluated with respect to mortality, loss of body weight and WBC and effects on somatostatin receptor-expressing organs. In all three experiments, only one animal died after the administration of AN-238, two animals after the injection of AN-201, and one death also occurred in a control group. Loss of body weight was observed in all treatment groups as compared to controls except for animals that received the carrier alone. However, in mice treated with AN-238 loss of weight was less severe and animals regained weight faster than those receiving AN-201. No macroscopic changes or weight differences were found in somatostatin receptor-positive organs. Myelotoxicity is considered the most serious side-effect and the dose-limiting factor of chemotherapy. In our study, AN-238 did not significantly reduce WBC at any time, while eight days after the injection of AN-201 a significant decrease in WBC was found in all three experiments. Some of the systemic toxicity observed in this study, including a loss of body weight and a minor decrease of WBC after administration of AN-238, may be caused by a high esterase activity in mouse serum, which cleaves the ester bond of AN-238 and releases AN-201 in the circulation (44). However, serum esterase activity is much lower in humans than in mice (44). Therefore, it can be assumed that toxicity of AN-238 in patients would be further decreased. In previous studies, we demonstrated a significant reduction in toxicity of $\mathrm{AN}-238$ in mice pretreated with an esterase inhibitor $(44,45)$. Accordingly, in preliminary studies with radiolabeled somatostatin analogues, no or only low toxicity was observed in patients, at doses causing objective therapeutic responses (46-48).

Recent in vitro findings suggest that targeted therapy with the cytotoxic LHRH analogue AN-152 may delay the development of resistance to chemotherapy in endometrial cancer (49). In our study, only cytotoxic radical AN-201, but not targeted cytotoxic somatostatin analogue AN-238 caused some induction of MDR-1 and LRP in MRI-H187 tumors. In MRI-H255 melanomas, no major changes of MDR-1 and LRP were found after administration of either compound. No induction of mRNA for MRP-1 occurred after treatment with AN-238 or AN-201. Thus, a rapid development of chemoresistance by targeted chemotherapy should not be expected.

In conclusion, our results demonstrate that cytotoxic somatostatin analogue AN-238 significantly inhibits growth of somatostatin receptor-positive human melanoma tumors.
AN-238 was more efficacious and less toxic than its radical AN-201. Consequently, the use of AN-238 could provide a novel and effective approach to the treatment of patients with metastatic melanomas.

\section{Acknowledgements}

This study was supported by the Medical research service of the Veterans Affairs Department and a grant from Zentaris GmbH (Frankfurt am Main, Germany) to Tulane University (all to A.V.S.). Gunhild Keller was supported by a fellowship within the post doctorate program of the German Academic Exchange Service (DAAD).

\section{References}

1. Jemal A, Murray T, Ward E, et al: Cancer statistics, 2005. CA Cancer J Clin 54: 8-29, 2005.

2. Barth A, Wanek LA and Morton DL: Prognostic factors in 1,521 melanoma patients with distant metastases. J Am Coll Surg 181: 193-201, 1995.

3. Karakousis CP, Velez A, Driscoll DL and Takita H: Metastasectomy in malignant melanoma. Surgery 115: 295-302, 1994.

4. Hsueh EC, Essner R, Foshag LJ, et al: Prolonged survival after complete resection of disseminated melanoma and active immunotherapy with a therapeutic cancer vaccine. J Clin Oncol 20: 4549-4554, 2002.

5. Hill GJ II, Krementz ET and Hill HZ: Dimethyl triazeno imidazole carboxamide and combination therapy for melanoma. IV. Late results after complete response to chemotherapy (Central Oncology Group protocols 7130, 7131, and 7131A). Cancer 53: 1299-1305, 1984.

6. Comis RL: DTIC (NSC-45388) in malignant melanoma: a perspective. Cancer Treat Rep 60: 165-176, 1976.

7. Chan AD and Morton DL: Active immunotherapy with allogenetic tumor cell vaccines: present status. Semin Oncol 25: 611-622, 1998.

8. Lens MB and Eisen TG: Systemic chemotherapy in the treatment of malignant melanoma. Expert Opin Pharmacother 4: 2205-2211, 2003.

9. Kefford RF: Adjuvant therapy of cutaneous melanoma: the interferon debate. Ann Oncol 14: 358-365, 2003.

10. Lens MB: The role of biological response modifiers in malignant melanoma. Expert Opin Biol Ther 3: 1225-1231, 2003.

11. Magrath IT: Targeted approaches to cancer therapy. Int J Cancer 56: 163-166, 1994.

12. Begent RH: UICC/CRC conference on targeted cancer therapy. Royal Free Hospital School of Medicine, London, 1991. Int J Cancer 55: 355-358, 1993.

13. Abou-Jawde R, Choueiri T, Alemany C and Mekhail T: An overview of targeted treatments in cancer. Clin Ther 25: 2121-2137, 2003.

14. Trail PA, King HD and Dubowchik GM: Monoclonal antibody drug immunoconjugates for targeted treatment of cancer. Cancer Immunol Immunother 52: 328-337, 2003.

15. Schally AV and Nagy A: New approaches to treatment of various cancers based on cytotoxic analogs of LHRH, somatostatin and bombesin. Life Sci 72: 2305-2320, 2003.

16. Schally AV and Nagy A: Chemotherapy targeted to cancers through tumoral hormone receptors. Trends Endocrinol Metab 15: 300-310, 2004.

17. Schally AV, Comaru-Schally AM, Nagy A, Kovacs M, Szepeshazi K, Plonowski A, Varga JL and Halmos G: Hypothalamic hormones and cancer. Front Neuroendocrinol 22: 248-291, 2001.

18. Koppan M, Nagy A, Schally AV, Arencibia JM, Plonowski A and Halmos G: Targeted cytotoxic analogue of somatostatin AN-238 inhibits growth of androgen-independent Dunning R3327-AT-1 prostate cancer in rats at nontoxic doses. Cancer Res 58: 4132-4137, 1998.

19. Plonowski A, Schally AV, Nagy A, Sun B and Szepeshazi K: Inhibition of PC-3 human androgen-independent prostate cancer and its metastases by cytotoxic somatostatin analogue AN-238. Cancer Res 59: 1947-1953, 1999. 
20. Kahan Z, Nagy A, Schally AV, Hebert F, Sun B, Groot K and Halmos G: Inhibition of growth of MX-1, MCF-7-MIII and MDA-MB-231 human breast cancer xenografts after the administration of a targeted cytotoxic analog of somatostatin, AN-238. Int J Cancer 82: 592-598, 1999.

21. Kiaris H, Schally AV, Nagy A, Sun B, Szepeshazi K and Halmos G: Regression of U-87 MG human glioblastomas in nude mice after treatment with a cytotoxic somatostatin analog AN-238. Clin Cancer Res 6: 709-717, 2000.

22. Keller G, Engel JB, Schally AV, Nagy A, Hammann B and Halmos G: Growth inhibition of experimental non-Hodgkin's lymphomas with the targeted cytotoxic somatostatin analogue AN-238. Int J Cancer 114: 831-835, 2005.

23. Letsch M, Schally AV, Szepeshazi K, Halmos G and Nagy A: Effective treatment of experimental androgen sensitive and androgen independent intraosseous prostate cancer with targeted cytotoxic somatostatin analogue AN-238. J Urol 171: 911-915, 2004.

24. Lum SS, Fletcher WS, O'Dorisio MS, Nance RW, Pommier RF and Caprara M: Distribution and functional significance of somatostatin receptors in malignant melanoma. World J Surg 25: 407-412. 2001.

25. Fletcher WS, Lum SS, Nance RW, Pommier RF and O'Dorisio MS: The current status of somatostatin receptors in malignant melanoma. Yale J Biol Med 70: 561-563, 1997.

26. Virgolini I, Leimer M, Handmaker $\mathrm{H}$, et al: Somatostatin receptor subtype specificity and in vivo binding of a novel tumor tracer, 99mTc-P829. Cancer Res 58: 1850-1859, 1998

27. Cole SP, Bhardwaj G, Gerlach JH, et al: Overexpression of a transporter gene in a multidrug-resistant human lung cancer cell line. Science 258: 1650-1654, 1992

28. Scheffer GL, Wijngaard PL, Flens MJ, et al: The drug resistancerelated protein LRP is the human major vault protein. Nat Med 1: 578-582, 1995

29. Scheper RJ, Broxterman HJ, Scheffer GL, et al: Overexpression of a M(r) 110,000 vesicular protein in non-P-glycoproteinmediated multidrug resistance. Cancer Res 53: 1475-1479, 1993.

30. Schadendorf D, Makki A, Stahr C, et al: Membrane transport proteins associated with drug resistance expressed in human melanoma. Am J Pathol 147: 1545-1552, 1995.

31. Nagy A, Armatis P and Schally AV: High yield conversion of doxorubicin to 2-pyrrolinodoxorubicin, an analog 500-1000 times more potent: structure-activity relationship of daunosaminemodified derivatives of doxorubicin. Proc Natl Acad Sci USA 93: 2464-2469, 1996.

32. Cai RZ, Szoke B, Lu R, Fu D, Redding TW and Schally AV: Synthesis and biological activity of highly potent octapeptide analogs of somatostatin. Proc Natl Acad Sci USA 83: 1896-1900, 1986.

33. Nagy A, Schally AV, Halmos G, et al: Synthesis and biological evaluation of cytotoxic analogs of somatostatin containing doxorubicin or its intensely potent derivative, 2-pyrrolinodoxorubicin. Proc Natl Acad Sci USA 95: 1794-1799, 1998.

34. Halmos G, Schally AV, Sun B, Davis R, Bostwick DG and Plonowski A: High expression of somatostatin receptors and messenger ribonucleic acid for its receptor subtypes in organconfined and locally advanced human prostate cancers. J Clin Endocrinol Metab 85: 2564-2571, 2000.
35. Halmos G, Sun B, Schally AV, Hebert F and Nagy A: Human ovarian cancers express somatostatin receptors. J Clin Endocrinol Metab 85: 3509-3512, 2000

36. Bajo AM, Schally AV, Halmos G and Nagy A: Targeted doxorubicin-containing luteinizing hormone-releasing hormone analogue AN-152 inhibits the growth of doxorubicin-resistant MX-1 human breast cancers. Clin Cancer Res 9: 3742-3748, 2003.

37. Bajo AM, Schally AV, Krupa M, Hebert F, Groot K and Szepeshazi K: Bombesin antagonists inhibit growth of MDAMB-435 estrogen-independent breast cancers and decrease the expression of the ErbB-2/HER-2 oncoprotein and c-jun and c-fos oncogenes. Proc Natl Acad Sci USA 99: 3836-3841, 2002.

38. Szepeshazi K, Schally AV, Nagy A, Wagner BW, Bajo AM and Halmos G: Preclinical evaluation of therapeutic effects of targeted cytotoxic analogs of somatostatin and bombesin on human gastric carcinomas. Cancer 98: 1401-1410, 2003

39. Rasmussen WC: Quantification on the LightCycler. In: Rapid Cycle Real-time PCR, Methods and Applications. Meuer S, Wittwer CT and Nakagawara K (eds). Springer Press, Heidelberg, pp21-34, 2001

40. Pfaffl MW: A new mathematical model for relative quantification in real-time RT-PCR. Nucleic Acids Res 29: 45, 2001.

41. Morton DL, Essner R, Kirkwood JM and Wollman RC: Malignant melanoma. In: Cancer Medicine. Kufe DW, Pollock RE, Weichselbaum RR, Bast Jr RC, Gansler TS, Holland JF and Frei III E (eds). 6th edition, BC Dekker, Hamilton, Ontario, pp1973-1995, 2004.

42. Hwu WJ: New approaches in the treatment of metastatic melanoma: thalidomide and temozolomide. Oncology 14: 25-28, 2000.

43. Becker JC, Kampgen E and Brocker E: Classical chemotherapy for metastatic melanoma. Clin Exp Dermatol 25: 503-508, 2000

44. Nagy A, Plonowski A and Schally AV: Stability of cytotoxic luteinizing hormone-releasing hormone conjugate $(\mathrm{AN}-152)$ containing doxorubicin 14-O-hemiglutarate in mouse and human serum in vitro: implications for the design of preclinical studies. Proc Natl Acad Sci USA 97: 829-834, 2000.

45. Plonowski A, Nagy A, Schally AV, Sun B, Groot K and Halmos G: In vivo inhibition of PC-3 human androgenindependent prostate cancer by a targeted cytotoxic bombesin analogue, AN-215. Int J Cancer 88: 652-657, 2000.

46. Otte A, Mueller-Brand J, Dellas S, Nitzsche EU, Herrmann R and Maecke HR: Yttrium-90-labelled somatostatin-analogue for cancer treatment. Lancet 351: 417-418, 1998.

47. Wiseman GA and Kvols LK: Therapy of neuroendocrine tumors with radiolabeled MIBG and somatostatin analogues. Semin Nucl Med 25: 272-278, 1995.

48. McCarthy KE, Woltering EA, Espenan GD, Cronin M, Maloney TJ and Anthony LB: In situ radiotherapy with 111Inpentetreotide: initial observations and future directions. Cancer J Sci Am 4: 94-102, 1998.

49. Gunthert AR, Grundker C, Bongertz T, Schlott T, Nagy A, Schally AV and Emons G: Internalisation of cytotoxic analog AN-152 of luteinizing hormone-releasing hormone induces apoptosis in human endometrial and ovarian cancer cell lines independent of multidrug resistance-1 (MDR-1) system. Am J Obstet Gynecol 191: 1164-1172, 2004. 